\title{
Machine vision monitoring and particle size feed analysis
}

\begin{abstract}
This paper presents selected problems related to the use of machine vision techniques for the analysis of particle size distribution. The basic steps and conditions for acquiring granular material images are described, followed by further processing and analysis methods. The advantages of 3-D image acquisition and processing have been compared to 2-D image analysis. Several possible areas of application related to the supervision of material transportation, optimization of mineral processing systems, and bulk density measurements have also been presented.
\end{abstract}

Key words: particle size measurement, image analysis, coal preparation

\section{INTRODUCTION}

Vision is one of the most important senses, providing most of the information processed by the human mind. The efficiency of the visual assessment of the surrounding world leads to search for methods of algorithmical processing of visual information using modern computer technology. For many years, there have been made multiple attempts to use visual information in the area of mineral processing. The first applications of image processing for particle size analysis were used to evaluate rock fragmentation (e.g., in quarries) after blasting, as it was the most efficient method for analyzing the size of large rock blocks in cases when sieve analysis was not applicable. The first studies were based on an analysis of the scanned images obtained by the photochemical method. The results of blasting were evaluated in natural illumination on the basis of static images [1-4]. The development of modern video methods is closely linked to advances in optoelectronic technologies, reduced costs and increased performance of digital still and video cameras, and increased computing power necessary for the analysis of complex systems (i.e., involving a very large number of particles, especially in a high-resolution images). In addition to the particle size analysis of rocks in quarries and opencast mining, the analysis of particle size distribution in boxes of rail carriages or trucks $[4,5]$ as well as an analysis of microscopic images of the smallest particles in the aqueous environment [6] and fly ashes [7] can be considered as a potential area for video monitoring applications. In this paper, particular attention has been paid to the problem of monitoring the flow of particle stream movement on a conveyor belt [8].

\section{TWO-DIMENSIONAL IMAGE ACQUISITION}

Image acquisition (i.e., its registration by an appropriate optical and optoelectronic system as well as its conversion to the digital form) is the first element of the whole multi-step image processing chain, determining the efficiency of its further analysis [8, 9]. The basic stages of the of image acquisition process from the real-world scene to the final digital form are shown schematically in Figure 1.

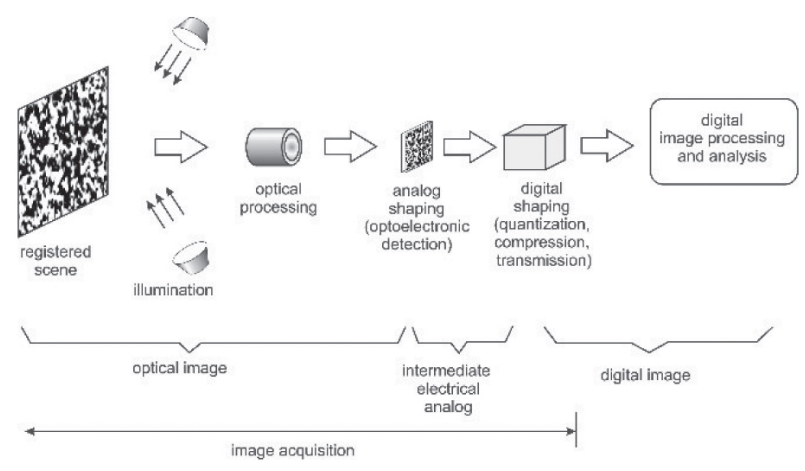

Fig. 1. Basic stages of image acquisition chain

In the case of coal particle size analysis, this task is particularly complex, as it is the most difficult type of rock to analyze due to its black surface color and the very low value of its surface reflection coefficient. 
An additional impediment is the carbon shine, which changes the direction of light reflection and makes it difficult to analyze the shape and size of the grain. The situation is even more difficult in the case of wet coal; for example, due to the spraying of water associated with dust control. The black color of the rubber conveyor belt (especially when wet) makes it difficult to separate the analyzed objects (i.e., coal particles) from the background. Due to the above-mentioned factors, the ratio of the useful signal (brightness changes related to the size and shape of the particle surface) to the noise signal related to specular reflections and non-homogeneous illumination for the coal particle stream is much lower than for other mineral raw materials. Therefore, the machine vision size analysis systems used in rock mining and metal ore processing have not found wider use in coal mining applications. They require the development of specialized algorithms that take into account the special conditions described above and provide the adequate quality of the input image necessary for further analysis. As the image (analog or digital) is always the result of light reflected from the surface of the observed particle surface, special attention should be paid to providing adequate illumination. The light reflection from the particle surface is described by Lambert's law, and the shaded inter-particle spaces are the primary means for separating the touching particles. The best results can therefore be achieved with mixed illumination with a dominant contribution of side illumination, as it does not over-illuminate the interparticle space [10].

Since only the surface layer of granular material is available for video analysis, there is the problem of evaluating the representativeness of this layer for the whole stream volume. Monte Carlo simulation studies [8] have shown that an important condition of this representativeness is to provide a relatively small layer thickness (i.e., comparable to the heightof the largest grains) and to measure at the beginning of the belt, where the influence of vibrational segregation (the mechanically induced falling of the finest particles into the free spaces between the larger grains) is still negligibly small.

\section{THREE-DIMENSIONAL IMAGE ACQUISITION}

The real surface of the granular material stream is a three-dimensional surface; hence, the common disadvantage of two-dimensional image (grayscale or color) analysis methods is the loss of direct depth information related to the third dimension (perpendicular to the two dimensions of the image plane) of both the individual particles as well as their entire population. Much more information can be obtained using the direct acquisition and analysis of three-dimensional images.

On the basis of the research carried out, it is possible to distinguish as particularly efficient (because of the use of the rectilinear motion of the conveyor belt) the following 3-D image acquisition methods $[8,11,12]$ :

- stereovision [13, 14],

- laser triangulation,

- Time-of-Flight measurement.

Figures 2 and 3 compare the two-dimensional grayscale image and the corresponding height map; i.e., the three-dimensional image obtained by the Time-of-Flight measurement method. In this way, the three-dimensional images resulting from 3-D acquisition are characterized by a lower sensitivity to light irregularities and light reflections from the grain surface and, above all, make direct measurement of the height of both particular grains and the entire surface of the material stream possible.

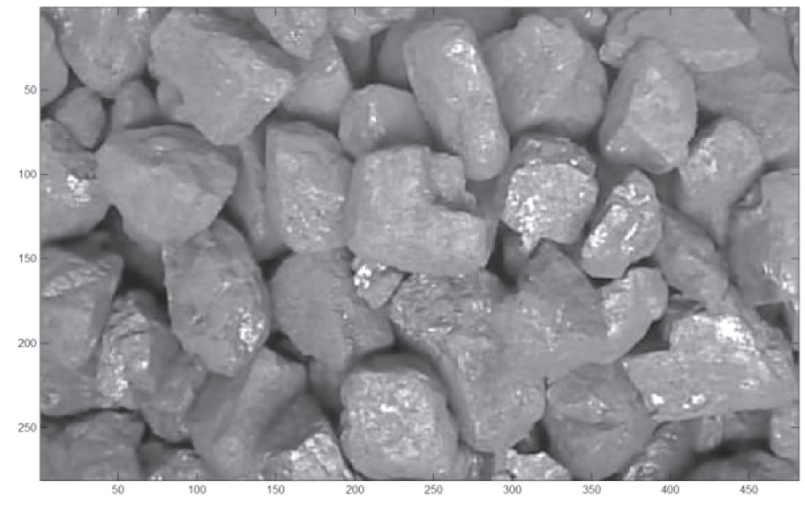

Fig. 2. Example area of coal stream surface

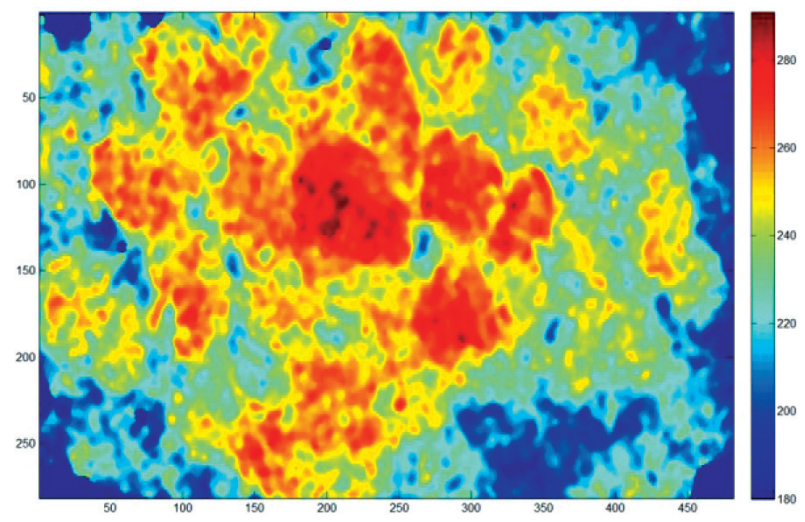

Fig. 3. Height map; i.e., three-dimensional image corresponding to surface of Figure 2 
This allows for a more accurate estimation of the volume and mass of individual particles and makes it possible to determine the bulk density of the material (useful in many applications). It should be emphasized that the processing methods of three-dimensional and two-dimensional images are very similar in many aspects because the deepest (i.e., smallest height) inter-particle spaces defining the contours of the individual particles are at the same time the darkest areas (i.e., they have the lowest level of brightness) because of the high particle surface slope and shading associated with impeded illumination input.

\section{IMAGE PROCESSING AND ANALYSIS}

After image acquisition (i.e., digital recording), it is often necessary to apply a preprocessing stage in order to eliminate the interference caused by irregular illumination and local specular reflections from the shining fragments of the particle surface. The analyses [6] show that, in the case of uneven illumination, the best results can be obtained by intensity normalization based on the reference light pattern recorded on an empty belt. In order to eliminate specular reflection, image smoothing must be done in an adaptive manner so as not to blur the particle contours, making it difficult to precisely position and measure them. One method may be nonlinear diffusion, which locally smooths individual image areas to a varying degree depending on their local brightness or height gradient magnitudes [15].

After defining the particle contour $[8,9]$, it is necessary to determine the particle size in a manner corresponding to its behavior during sieve analysis, because sieving is accepted as a reference method for widespread industrial use. Since grain behavior during the screening process is determined by the two smallest of three orthogonal dimensions, one-parameter approximation methods (such as the diameter of the equivalent circle or the side of a square with an equivalent surface area of the grain contour) are too simplistic. The solution of this problem can be obtained by the elliptic approximation method, which allows us to describe the shape of the particle contour by means of an inertia equivalent ellipse. Grain behavior in the sieving process is determined by the shorter axis of the ellipse. An example of an elliptical approximation of a particle contour is shown in Figure 4.

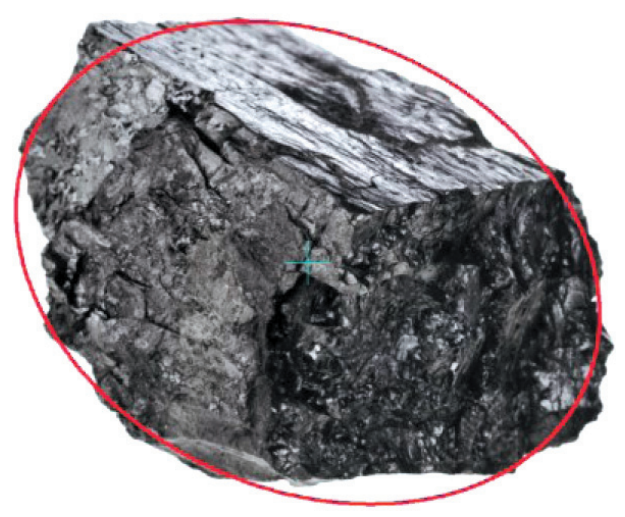

Fig. 4. Elliptical approximation of coal particle contour

For very fine particles, precise segmentation (which is necessary to individually describe and classify the individual particles) is a difficult and timeconsuming task. Hence, it is convenient to use an alternative method in these cases that treats the entire area (or selected fragment of the area) of the granular material stream as a texture with size-specific statistical parameters. As a size-describing function of a granular material image, a spatial autocorrelation function can be assumed, as its local maxima simply correspond to the particle size most commonly encountered in the image [16]. This real autocorrelation function of a non-homogenous material can be expressed as a weighted sum of several basis functions determined for homogeneous samples corresponding to the reference particle size classes. The weight coefficients correspond to the proportion of individual grain classes in the total material stream. It is particularly important to select the algorithm for determining these weighting factors in a way that ensures the best possible representation of the empirically determined spatial autocorrelation function of the image (in the sense of the least squares method) and at the same time guarantees the physical meaning (i.e., limiting the range of coefficients to non-negative values). A good solution in this case may be the use of the NNLS (Non-Negative Least Squares) method [17].

\section{POSSIBILITIES OF PRACTICAL APPLICATION}

One of the simplest and (at the same time) very important practical ways to use the machine vision monitoring of particle size distribution may be the 
detection of large (oversized) large grains (rock blocks) that may cause disturbances in the transportation process by jamming or damaging the reloading devices or other equipment [18]. Another area of the application of video monitoring can be the direct tuning of the mineral processing crucial parameters (e.g., separation densities). The case of gravitational enrichment in pulsation jigs can be particularly important, as these devices are the most sensitive to changes in particle size distribution. For different size classes, the shape of the separation curve changes the finer grains are separated less precisely than the coarser grains. Due to the fact that the feed passage time through the whole jig bed is relatively long, an on-line machine vision analysis of the feed particle size distribution at the jig inlet (Fig. 5) makes a much faster correction of the separation density value possible (especially in technological layouts with multiple jigs or multiple passage separation) than in a system equipped only with a radiometric ash monitor at the jig output.

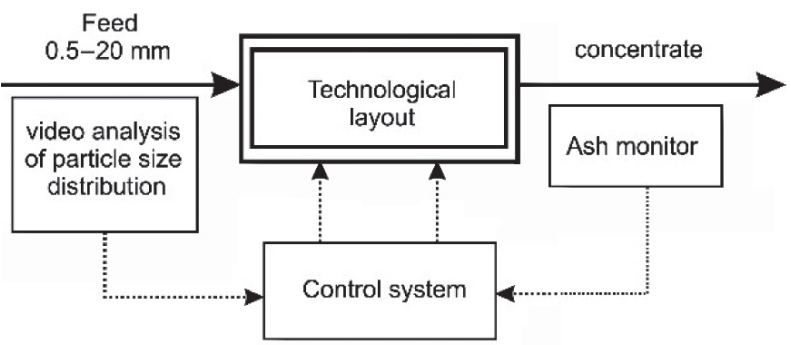

Fig. 5. Application of on-line machine-vision analysis of particle size distribution for continuous operation tuning of jig plant [8]

The calculations carried out in [8] show that, with high and frequent variability variation in the particle size distribution, application of the machine vision system can lead to a significant increase in the production value (achieved by the faster optimization of the separation densities in particular jigs). This can ensure a relatively quick cost reimbursement (in the order of several months or even weeks). In the case of 3-D image acquisition and processing, it is possible to extend monitoring system functionality by continuous measurement of the material stream bulk density (if the video monitoring system is connected to the conveyor belt scales [19]) and to control the uniformity of the material distribution on the conveyor belt. An example proposal of such a system is shown in Figure 6.

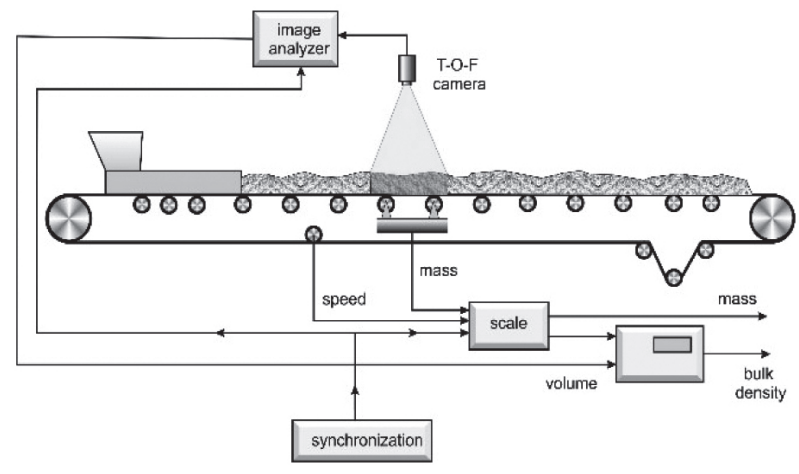

Fig. 6. Example of dynamic bulk density measurement of granular material stream

\section{CONCLUSIONS}

Advances in the field of optoelectronic technology make the development of video monitoring systems for grain size composition and the volume flow of raw material streams possible. Such systems can be used for the tuning of gravitational enrichment processes as well as for the video monitoring of belt conveyor system operation. The correct acquisition of two-dimensional images requires the proper illumination. Much more information can be obtained by using 3-D image acquisition and processing methods. Three-dimensional images contain direct information on the height of both the particular grains as well as the entire surface of the material stream.

References

[1] Latham J.P., Kemeny J., Maerz N., Noy M.: A blind comparison between results of four image analysis systems using a photo-library of piles of sieved fragments, "Fragblast" 2003, 7: 105-132.

[2] Maerz N.H.: Image sampling techniques and requirements for automated image analysis of rock fragmentation, Proceedings of the FRAGBLAST 5 Workshop on Measurement of Blast Fragmentation, Montreal 1996.

[3] Maerz N.H.: Online Fragmentation Analysis: Achievements in the Mining Industry, Centre for Aggregates Research (ICAR) Seventh Annual Symposium Proceedings, Austin 1999.

[4] Palangio T.W., Palangio T.C.: Maerz N.H.: Advanced automatic optical blast fragmentation sizing and tracking, European Federation of Explosives Engineers, Brighton 2005.

[5] Kemeny J., Devgan A., Hagaman R.: Analysis of Rock Fragmentation using Digital Image Processing, "Journal of Geotechnical Engineering” 1993, 119: 1144-1160.

[6] Trybalski K.: Kontrola, modelowanie $i$ optymalizacja procesów technologicznych przeróbki rud, Wydawnictwa $\mathrm{AGH}$, Kraków 2013.

[7] Szponder-Kołakowska D.K., Trybalski K.: Nowoczesne metody $i$ urzadzenia pomiarowe $w$ badaniu właściwości surowców i odpadów mineralnych, Wydawnictwa AGH, Kraków 2014. 
[8] Heyduk A.: Metody akwizycji i przetwarzania obrazów dwuwymiarowych $i$ trójwymiarowych $w$ wizyjnej analizie granulometrycznej, Monografia nr 669, Wydawnictwo Politechniki Śląskiej, Gliwice 2017.

[9] Heyduk A.: Etapy segmentacji obrazu w wizyjnym układzie analizy składu ziarnowego, "Mechanizacja i Automatyzacja Górnictwa" 2008, 1: 12-15.

[10] Heyduk A.: Wpływ warunków oświetleniowych na segmentację obrazu $w$ systemie wizyjnej analizy składu ziarnowego, "Mechanizacja i Automatyzacja Górnictwa” 2005, 10: 21-29.

[11] Heyduk A.: Laser triangulation in 3-dimensional granulometric analysis, "Archives of Mining Science" 2016, 1: 15-27.

[12] Heyduk A.: Metody stereowizyjne $w$ analizie składu ziarnowego, "Systemy Wspomagania w Inżynierii Produkcji" 2017, 2: 103-113.

[13] Cyganek B.: Wprowadzenie do pomiaru głębi obrazu za pomoca stereoskopowego układu kamer, "Przegląd Spawalnictwa" 2013, 3: 38-43.

[14] Cyganek B., Siebert P.J.: An introduction to 3D Computer Vision Techniques and Algorithms, John Wiley \& Sons, Chichester 2009.
[15] Heyduk A.: Morfologiczne i dyfuzyjne algorytmy wstępnego przetwarzania obrazu w układzie wizyjnej analizy składu ziarnowego, "Mechanizacja i Automatyzacja Górnictwa" 2006, 9: 39-46.

[16] Heyduk A.: Teksturowe (niesegmentacyjne) metody wizyjnej oceny składu ziarnowego, "Mechanizacja i Automatyzacja Górnictwa" 2010, 3: 16-24.

[17] Lawson C.L., Hanson R.J.: Solving Least Square Problems, SIAM, Philadelphia 1995.

[18] Cabello A., Sanchez M., Delgado J.: A New Approach to Identify Big Rocks with Applications to the Mining Industry, "Real-Time Imaging", 2002, 8: 1-9.

[19] Heyduk A.: Bulk density estimation using a 3-dimensional image acquisition and analysis system, Mineral Engineering Conference MEC 2016, Świeradów-Zdrój 2016.

ADAM HEYDUK, Ph.D., Eng. Faculty of Mining and Geology Silesian University of Technology ul. Akademicka 2, 44-100 Gliwice, Poland Adam.Heyduk@polsl.pl 


\title{
Wizyjny monitoring i analiza granulometryczna nadawy
}

\begin{abstract}
$W$ artykule przedstawiono wybrane zagadnienia zwiazane $z$ wykorzystaniem technik wizyjnych do celów analizy składu ziarnowego. Opisano podstawowe etapy i uwarunkowania akwizycji obrazów materiału ziarnistego, a następnie ich dalszego przetwarzania $i$ analizy. Sformułowano zalety akwizycji i przetwarzania obrazów trójwymiarowych $w$ porównaniu $z$ dwuwymiarowymi. Przedstawiono potencjalne obszary zastosowań związane z nadzorowaniem transportu materiałów, optymalizacja procesów wzbogacania grawitacyjnego oraz pomiarami gęstości nasypowej.
\end{abstract}

Słowa kluczowe: pomiary składu ziarnowego, analiza obrazu, przeróbka wegla

\section{WSTĘP}

Wzrok jest jednym z najważniejszych zmysłów, dostarczającym większość informacji przetwarzanych przez ludzki umysł. Efektywność wizualnej oceny otaczającego świata skłania do poszukiwania sposobów algorytmizacji przetwarzania informacji obrazowej z wykorzystaniem nowoczesnych środków techniki obliczeniowej. Od wielu lat podejmuje się próby wykorzystania informacji wizyjnej w przeróbce surowców mineralnych. Prace nad zastosowaniem przetwarzania obrazów do celów analizy granulometrycznej prowadzone były pod kątem oceny składu ziarnowego surowców skalnych (np. w kamieniołomach), gdyż była to najbardziej efektywna metoda określania rozmiaru dużych bloków skalnych, niepodlegających analizie sitowej. Pierwsze badania były realizowane na podstawie analizy skanowanych zdjęć uzyskanych metodą fotochemiczną. Efekty robót strzałowych oceniano $\mathrm{w}$ oświetleniu naturalnym na podstawie zdjęć statycznych [1-4]. Rozwój metod wizyjnych jest ściśle związany z postępem w dziedzinie technologii optoelektronicznych, obniżającym koszty i podwyższającym parametry dostępnych cyfrowych kamer i aparatów fotograficznych oraz wzrost mocy obliczeniowej systemów komputerowych umożliwiający przetwarzanie złożonych (tzn. obejmujących bardzo dużą liczbę ziaren, zwłaszcza odwzorowanych w wysokiej rozdzielczości). Oprócz analizy granulometrycznej skał w kamieniołomach i górnictwie odkrywkowym jako potencjalny obszar zastosowań monitoringu wizyjnego wymienić można analizę składu ziarnowego urobku w skrzyniach wozów kolejowych lub samochodów ciężarowych [4, 5] oraz analizę mikroskopowych obrazów najdrobniejszych ziaren w środowisku wodnym [6] oraz popiołów lotnych [7]. W niniejszej pracy skoncentrowano się na zagadnieniu monitoringu strumienia ziaren przemieszczających się na taśmie przenośnika [8].

\section{AKWIZYCJA OBRAZÓW DWUWYMIAROWYCH}

Akwizycja obrazu, czyli jego pozyskanie (przez odpowiedni układ optyczny, a następnie optoelektroniczny) i zachowanie w postaci cyfrowej, jest pierwszym elementem wieloetapowego przetwarzania obrazu, warunkującym efektywność jego dalszej analizy $[8,9]$. Podstawowe etapy procesu akwizycji obrazu od obiektu rzeczywistego aż do postaci cyfrowej przedstawiono schematycznie na rysunku 1 .

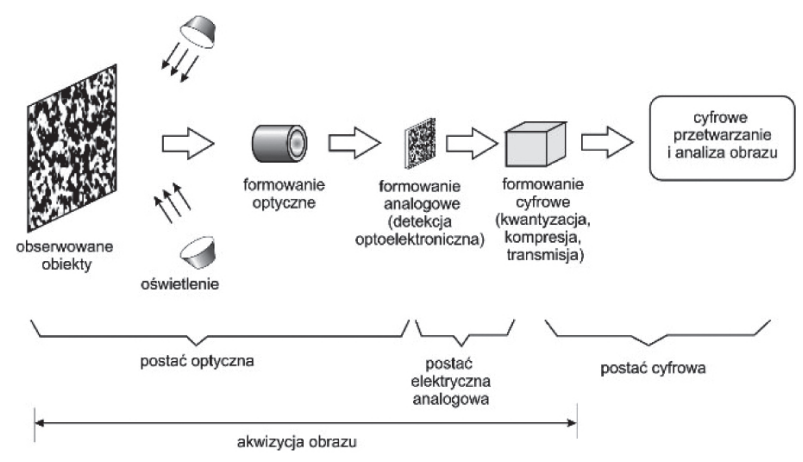

Rys. 1. Podstawowe etapy akwizycji obrazu 
W przypadku analizy ziaren węgla kamiennego zadanie to jest szczególnie skomplikowane, gdyż jest to skała najtrudniejsza do analizy wizyjnej ze względu na czarną barwę i związaną z tym bardzo niską wartość współczynnika odbicia światła. Dodatkowym utrudnieniem jest występujący w przypadku węgla połysk, zmieniający kierunek odbicia światła i utrudniający analizę kształtu i rozmiaru ziarna. Jeszcze trudniejsza staje się sytuacja w przypadku węgla mokrego, np. w wyniku zraszania wodą związanego ze zwalczeniem zapylenia. Można tu jeszcze wspomnieć o czarnym kolorze gumowej taśmy przenośnika zwłaszcza mokrej - utrudniającym wyodrębnienie analizowanych obiektów (czyli ziaren) od tła. Z uwagi na wyżej wymienione czynniki stosunek sygnału użytecznego - czyli zmian jasności związanych z rozmiarem i kształtem powierzchni ziaren do szumu związanego z odbiciami i niejednorodnym oświetleniem jest w przypadku węgla znacznie mniej korzystny niż w przypadku innych surowców mineralnych. Dlatego też systemy analizy wizyjnej - choć stosowane w górnictwie skalnym i rud metali, nie znalazły dotąd szerszego zastosowania w górnictwie węglowym. Wymaga to bowiem opracowania wyspecjalizowanych algorytmów uwzględniających powyższe uwarunkowania oraz zapewnienia odpowiedniej jakości obrazu wejściowego. Ponieważ obraz (analogowy lub cyfrowy) jest zawsze wynikiem odbicia światła od powierzchni obserwowanych obiektów (ziaren) to szczególną uwagę należy zwrócić na zapewnienie odpowiedniego oświetlenia. Zjawisko odbicia światła od powierzchni ziarna opisane jest prawem Lamberta, a podstawowym elementem pozwalającym wyodrębnić stykające się ze sobą ziarna są zacienione przestrzenie międzyziarnowe. Dlatego najlepsze efekty uzyskuje się przy oświetleniu mieszanym, z dominującym udziałem oświetlenia bocznego, ponieważ nie rozświetla ono nadmiernie przestrzeni międzyziarnowych [10].

W analizie wizyjnej dostępna jest jedynie powierzchniowa warstwa materiału ziarnistego, dlatego powstaje problem oceny reprezentatywności tej warstwy dla całości strumienia. Przeprowadzone z wykorzystaniem metody Monte Carlo badania symulacyjne [8] wykazały, że istotnym warunkiem tej reprezentatywności jest zapewnienie stosunkowo niewielkiej (tzn. porównywalnej z wysokością największych ziaren) grubości warstwy oraz dokonywanie pomiaru na początku taśmy - czyli tam, gdzie wpływ zjawiska segregacji wibracyjnej - powodującej wpadanie mniej- szych ziaren pomiędzy większe - jest jeszcze pomijalnie mały.

\section{AKWIZYCJA OBRAZÓW TRÓJWYMIAROWYCH}

Rzeczywista powierzchnia strumienia materiału ziarnistego jest trójwymiarowa. Stąd też wspólną wadą metod związanych $\mathrm{z}$ analizą obrazów dwuwymiarowych (monochromatycznych lub wielobarwnych) jest utrata bezpośredniej informacji związanej z trzecim - tzn. prostopadłym do dwóch wymiarów płaszczyzny obrazu - wymiarem zarówno pojedynczych ziaren, jak i całego ich zbioru. Stąd też znacznie pełniejszą informację można uzyskać, stosując akwizycję, a następnie analizę obrazów trójwymiarowych. Na podstawie przeprowadzonych badań można tu wyróżnić jako szczególnie efektywne (bo wykorzystujące prostoliniowy ruch taśmy przenośnika) metody $[8,11,12]$ :

- stereowizję [13, 14],

- triangulację laserową,

- pomiar czasu przelotu sygnału (T-o-F Time of Flight).

Na rysunkach 2 i 3 porównano obraz dwuwymiarowy i odpowiadającą mu mapę wysokości, czyli obraz trójwymiarowy uzyskany metodą pomiaru czasu przelotu. Uzyskiwane w ten sposób obrazy trójwymiarowe charakteryzują się - w porównaniu z obrazami dwuwymiarowymi - mniejszą wrażliwością na nierównomierność oświetlenia oraz odblaski światła od powierzchni ziaren, a przede wszystkim umożliwiają bezpośredni pomiar wysokości zarówno poszczególnych ziaren, jak i całej powierzchni strumienia materiału.

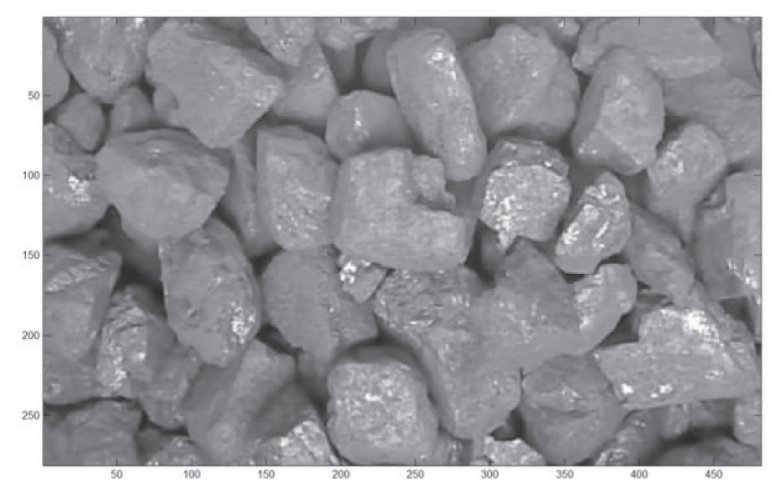

Rys. 2. Przykładowy fragment powierzchni strumienia węgla 


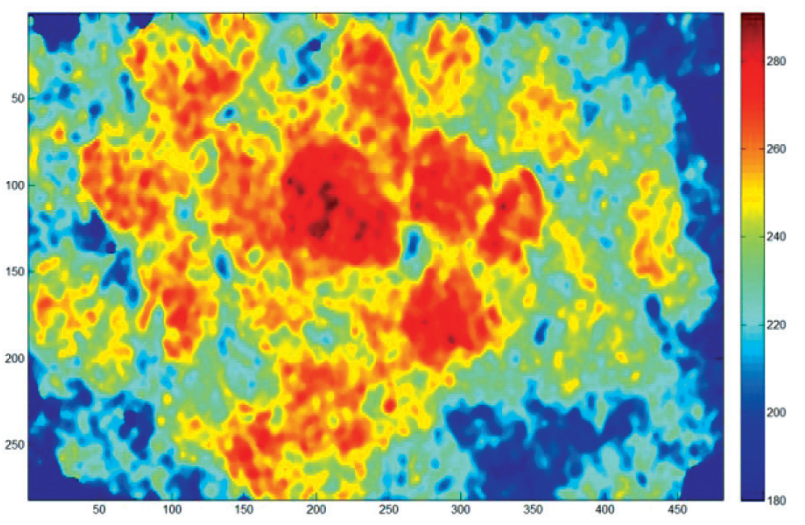

\section{Rys. 3. Mapa wysokości, czyli obraz trójwymiarowy odpowiadajacy powierzchni z rysunku 2}

Umożliwia to dokładniejsze oszacowanie objętości i masy ziaren oraz wyznaczenie - przydatnej w wielu zastosowaniach - gęstości nasypowej strumienia materiału. Należy podkreślić, że metody przetwarzania obrazów trójwymiarowych i dwuwymiarowych są do siebie $\mathrm{w}$ wielu aspektach bardzo zbliżone $\mathrm{z}$ uwagi na fakt, że najgłębsze (czyli o najmniejszej wysokości) obszary przestrzeni międzyziarnowych, wyznaczające kontury poszczególnych ziaren są jednocześnie obszarami najciemniejszymi, czyli charakteryzują się najniższym poziomem jasności $-\mathrm{z}$ uwagi na duże nachylenie ścian ziaren oraz zacienienie związane $\mathrm{z}$ utrudnionym dopływem światła.

\section{PRZETWARZANIE I ANALIZA OBRAZU}

Po dokonaniu akwizycji obrazu (czyli zarejestrowaniu go w postaci cyfrowej) niezbędne jest jego wstępne przetworzenie w celu likwidacji zakłóceń wywołanych nierównomiernością oświetlenia oraz lokalnymi odblaskami od błyszczących fragmentów powierzchni ziaren. Przeprowadzone analizy [10] wykazały, że w przypadku nierównomierności oświetlenia najlepsze efekty można uzyskać, stosując normalizację oświetlenia na podstawie nierównomierności wzorcowej zarejestrowanej na pustej taśmie. Wygładzanie obrazu - w celu likwidacji odblasków - musi być dokonywane w sposób adaptacyjny, tak aby nie doprowadzić do „rozmycia” krawędzi ziaren, utrudniających ich precyzyjną lokalizację. Jednym ze sposobów może być metoda nieliniowej dyfuzji, wygładzającej poszczególne obszary obrazu w stopniu zależnym od występującego w nich gradientu jasności lub wysokości [15].
Po określeniu konturu ziarna [8,9] niezbędne jest wyznaczenie rozmiarów ziarna w sposób odpowiadający jego zachowaniu w trakcie analizy sitowej, przyjmowanej - ze względu na szerokie rozpowszechnienie w przemyśle - jako metoda odniesienia. Ponieważ o zachowaniu ziarna $\mathrm{w}$ trakcie procesu przesiewania decydują dwa najmniejsze spośród trzech wymiarów, to metody aproksymacji jednoparametrowej (np. średnica zastępczego koła lub bok kwadratu o powierzchni równoważnej powierzchni wnętrza konturu ziarna) stanowią zbyt duże uproszczenie. Rozwiązaniem tego problemu może być metoda aproksymacji eliptycznej, pozwalająca opisać kształt konturu ziarna za pomocą zastępczej elipsy. O zachowaniu ziarna w procesie przesiewania decyduje wówczas krótsza oś elipsy. Przykład eliptycznej aproksymacji konturu ziarna przedstawiono na rysunku 4.

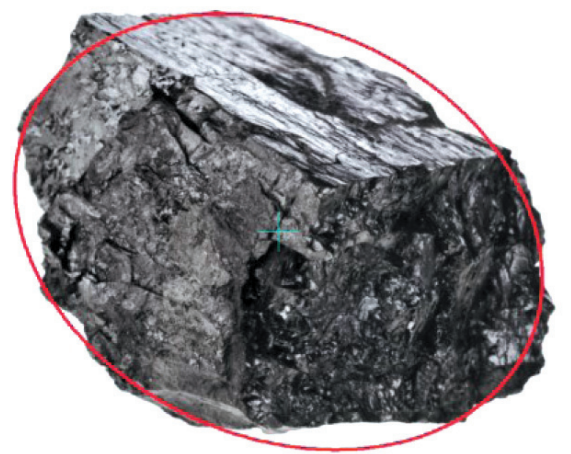

Rys. 4. Przykład eliptycznej aproksymacji konturu ziarna

W przypadku ziaren bardzo drobnych precyzyjna segmentacja - pozwalająca indywidualnie opisać i zaklasyfikować poszczególne ziarna - jest zadaniem trudnym i czasochłonnym. Stąd też w tych przypadkach dogodne jest zastosowanie metody alternatywnej, traktującej cały obszar (lub fragment obszaru) strumienia materiału jako teksturę o określonych parametrach statystycznych. Jako funkcję dobrze opisującą obraz materiału ziarnistego można przyjąć funkcję autokorelacji ze względu na fakt, że jej lokalne maksima w prosty sposób odpowiadają najczęściej spotykanym w danym obrazie rozmiarom ziaren [16]. Funkcję taką dla materiału o zróżnicowanym uziarnieniu można wyrazić jako sumę ważoną kilku funkcji wyznaczonych dla próbek jednorodnych odpowiadających „wzorcowym” klasom ziarnowym. Współczynniki wagowe odpowiadają wówczas udziałom poszczególnych klas ziarnowych w całości strumienia materiału. Szczególnie istotny jest tutaj dobór algorytmu wyznaczania tych współczynników wagowych 
w sposób zapewniający możliwie najlepsze (w sensie metody najmniejszych kwadratów) odwzorowanie wyznaczonej empirycznie funkcji autokorelacji obrazu, a jednocześnie gwarantujący sens fizyczny, czyli ograniczenie zakresu zmienności współczynników do wartości nieujemnych. Dobrym rozwiązaniem może tu być zastosowanie metody NNLS (Non-Negative Least Squares) [17].

\section{MOŻLIWOŚCI PRAKTYCZNEGO WYKORZYSTANIA}

Jednym z najprostszych - a jednocześnie istotnych z praktycznego punktu widzenia - sposobów wykorzystania wizyjnego monitoringu składu ziarnowego może być detekcja zbyt dużych ziaren (bloków skalnych) mogących spowodować zakłócenia w procesie transportowym, przez zablokowanie lub uszkodzenie urządzeń przeładowczych [18]. Kolejnym obszarem zastosowań monitoringu wizyjnego może być bezpośrednie sterowanie parametrami procesów przeróbczych (np. gęstością rozdziału). Szczególne znaczenie może to mieć w przypadku wzbogacania grawitacyjnego w osadzarkach pulsacyjnych, ponieważ są to urządzenia najbardziej wrażliwe na zmiany składu ziarnowego. W przypadku różnych klas ziarnowych zmienia się kształt krzywej rozdziału - ziarna drobniejsze wzbogacane są mniej dokładnie niż ziarna grubsze. $\mathrm{Z}$ uwagi na fakt, że czas przejścia nadawy przez łoże osadzarki jest stosunkowo długi, to - prowadzona w czasie rzeczywistym - wizyjna analiza składu ziarnowego nadawy na wejściu osadzarki (rys. 5) pozwala znacznie szybciej skorygować wartość gęstości rozdziału (zwłaszcza w układach $\mathrm{z}$ wieloma osadzarkami lub z wzbogacaniem wielokrotnym) niż w przypadku układu wyposażonego jedynie w popiołomierz radiometryczny na wyjściu osadzarki.

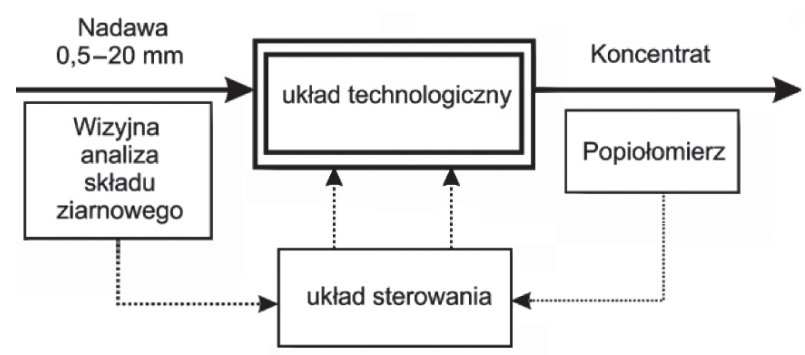

Rys. 5. Wykorzystanie ciagtej wizyjnej analizy składu ziarnowego do sterowania praca uktadu technologicznego osadzarki [8]
Obliczenia przeprowadzone w [8] wskazują, że przy dużej i częstej zmienności składu ziarnowego może to prowadzić do istotnego wzrostu wartości produkcji (uzyskanego przez szybszą optymalizację gęstości rozdziału w poszczególnych osadzarkach), zapewniającego stosunkowo szybki zwrot poniesionych nakładów inwestycyjnych (rzędu kilkunastu lub kilkudziesięciu dni). W przypadku akwizycji i przetwarzania obrazów trójwymiarowych możliwe jest rozszerzenie funkcjonalności układów monitorujących o ciągły pomiar gęstości nasypowej strumienia materiału (jeśli układ monitoringu wizyjnego sprzężony jest $\mathrm{z}$ wagą taśmociągową [19]) oraz o kontrolę równomierności rozłożenia materiału na taśmie przenośnika. Przykład propozycji takiego systemu przedstawiono na rysunku 6.

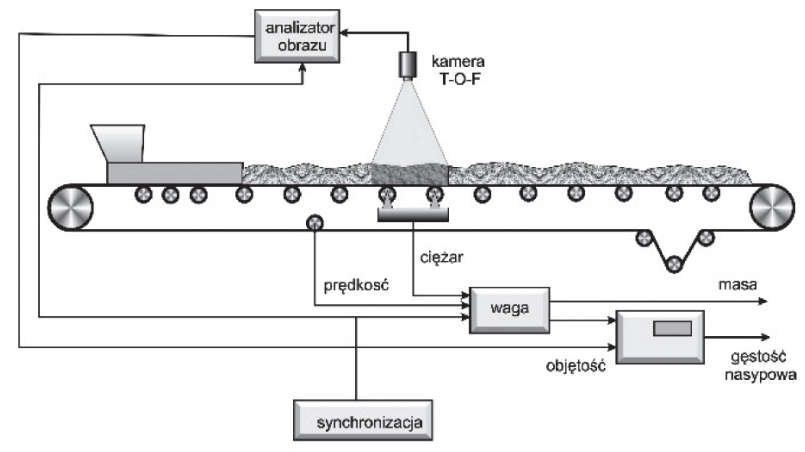

Rys. 6. Przyktad dynamicznego pomiaru gęstości nasypowej strumienia materiatu

\section{PODSUMOWANIE}

Postęp w dziedzinie technologii optoelektronicznych umożliwia tworzenie układów wizyjnego monitoringu składu ziarnowego oraz objętości strumienia surowców mineralnych. Układy takie mogą znaleźć zastosowanie w optymalizacji procesów wzbogacania grawitacyjnego oraz $\mathrm{w}$ układach monitoringu pracy układów transportowych. Poprawna akwizycja obrazów dwuwymiarowych wymaga odpowiedniego oświetlenia. Pełniejszą informację można uzyskać, stosując metody akwizycji i przetwarzania obrazów trójwymiarowych, zawierających bezpośrednią informację o wysokości zarówno poszczególnych ziaren, jak i całej powierzchni strumienia materiału.

\section{Literatura}

[1] Latham J.P., Kemeny J., Maerz N., Noy M.: A blind comparison between results of four image analysis systems using a photolibrary of piles of sieved fragments, „Fragblast” 2003, 7: 105-132. 
[2] Maerz N.H.: Image sampling techniques and requirements for automated image analysis of rock fragmentation, Proceedings of the FRAGBLAST 5 Workshop on Measurement of Blast Fragmentation, Montreal 1996.

[3] Maerz N.H.: Online Fragmentation Analysis: Achievements in the Mining Industry, Centre For Aggregates Research (ICAR) Seventh Annual Symposium Proceedings, Austin 1999.

[4] Palangio T.W., Palangio T.C., Maerz N.H.: Advanced automatic optical blast fragmentation sizing and tracking, European Federation of Explosives Engineers, Brighton 2005.

[5] Kemeny J., Devgan A., Hagaman R.: Analysis of Rock Fragmentation using Digital Image Processing, ,Journal of Geotechnical Engineering” 1993, 119: 1144-1160.

[6] Trybalski K.: Kontrola, modelowanie $i$ optymalizacja procesów technologicznych przeróbki rud, Wydawnictwa $\mathrm{AGH}$, Kraków 2013.

[7] Szponder-Kołakowska D.K., Trybalski K.: Nowoczesne metody $i$ urzadzenia pomiarowe $w$ badaniu wtaściwości surowców i odpadów mineralnych, Wydawnictwa AGH, Kraków 2014.

[8] Heyduk A.: Metody akwizycji i przetwarzania obrazów dwuwymiarowych i trójwymiarowych $w$ wizyjnej analizie granulometrycznej, Monografia nr 669, Wydawnictwo Politechniki Śląskiej, Gliwice 2017.

[9] Heyduk A.: Etapy segmentacji obrazu $w$ wizyjnym układzie analizy składu ziarnowego, „Mechanizacja i Automatyzacja Górnictwa" 2008, 1: 12-15.

[10] Heyduk A.: Wpływ warunków oświetleniowych na segmentację obrazu $w$ systemie wizyjnej analizy składu ziarnowego, „Mechanizacja i Automatyzacja Górnictwa” 2005, 10: 21-29.

[11] Heyduk A.: Laser triangulation in 3-dimensional granulometric analysis, „Archives of Mining Science” 2016, 1: 15-27.
[12] Heyduk A.: Metody stereowizyjne w analizie składu ziarnowego, „Systemy Wspomagania w Inżynierii Produkcji” 2017, 2: 103-113.

[13] Cyganek B.: Wprowadzenie do pomiaru gtębi obrazu za pomoca stereoskopowego układu kamer, „Przegląd Spawalnictwa” 2013, 3: 38-43.

[14] Cyganek B., Siebert P.J.: An introduction to 3D Computer Vision Techniques and Algorithms, John Wiley \& Sons, Chichester 2009.

[15] Heyduk A.: Morfologiczne i dyfuzyjne algorytmy wstepnego przetwarzania obrazu $w$ układzie wizyjnej analizy składu ziarnowego, „Mechanizacja i Automatyzacja Górnictwa” 2006, 9: 39-46.

[16] Heyduk A.: Teksturowe (niesegmentacyjne) metody wizyjnej oceny składu ziarnowego, „Mechanizacja i Automatyzacja Górnictwa" 2010, 3: 16-24.

[17] Lawson C.L., Hanson R.J.: Solving Least Square Problems, SIAM, Philadelphia 1995.

[18] Cabello A., Sanchez M., Delgado J.: A New Approach to Identify Big Rocks with Applications to the Mining Industry, „Real-Time Imaging” 2002, 8: 1-9.

[19] Heyduk A.: Bulk density estimation using a 3-dimensional image acquisition and analysis system, Mineral Engineering Conference MEC 2016, Świeradów-Zdrój 2016.

dr inż. ADAM HEYDUK

Wydziat Górnictwa i Geologii Politechnika Ślaska ul. Akademicka 2, 44-100 Gliwice Adam.Heyduk@polsl.pl 